\title{
The Adult CNS Retains the Potential to Direct Region-Specific Differentiation of a Transplanted Neuronal Precursor Cell Line
}

\author{
Lamya S. Shihabuddin, ${ }^{1,2}$ Jeffrey A. Hertz, ${ }^{2}$ Vicky R. Holets, ${ }^{1,2,3,4, a}$ and Scott R. Whittemore, ${ }^{1,2,3,5}$ \\ ${ }^{1}$ Neuroscience Program, ${ }^{2}$ The Miami Project to Cure Paralysis, and Departments of ${ }^{3}$ Neurological Surgery, ${ }^{4}$ Cell \\ Biology and Anatomy, and ${ }^{5}$ Physiology and Biophysics, University of Miami School of Medicine, Miami, \\ Florida 33136
}

\begin{abstract}
The chronic survival and differentiation of the conditionally immortalized neuronal cell line, RN33B, was examined following transplantation into the adult and neonatal rat hippocampus and cerebral cortex. In clonal culture, differentiated RN33B cells express p75 $5^{\text {NTR }}$ and trkB mRNA and protein, and respond to brain-derived neurotrophic factor treatment by inducing c-fos mRNA. Transplanted cells, identified using immunohistochemistry to detect $\beta$-galactosidase expression, were seen in most animals up to 24 weeks posttransplantation (the latest time point examined). Stably integrated cells with various morphologies consistent with their transplantation site were observed. In the cerebral cortex, many RN33B cells differentiated with morphologies similar to pyramidal neurons and stellate cells. In the hippocampal formation, many RN33B cells assumed morphologies similar to pyramidal neurons characteristic of CA1 and CA3 regions, granular cell layer neurons of the dentate gyrus, and polymorphic neurons of the hilar region. Identical morphologies were observed in both adult and neonatal hosts, although a greater percentage of $\beta$-galactosidase immunoreactive cells had differentlated in the neonatal brains. These results suggest that RN33B cells have the developmental plasticity to respond to local microenvironmental signals and that the adult brain retains the capacity to direct the differentiation of neuronal precursor cells in a direction that is consistent with that of endogenous neurons.
\end{abstract}

[Key words: neuronal cell line, immortalization, transplantation, differentiation, hippocampus, cerebral cortex]

Spontaneous regeneration in the mammalian CNS is limited, so injury or disease usually results in permanent loss of function. Neural transplantation is one potential therapeutic approach to restore function in the injured, degenerating, or aging CNS (Björklund, 1991; Emerich et al., 1992). Transplanted fetal CNS

\footnotetext{
Received Apr. 5, 1995; revised May 24, 1995; accepted May 31, 1995.

We thank Dr. Ellen Barrett for critically reviewing the manuscript, Linda A. White for her expertise with the organotypic cultures and her insightful suggestions throughout the course of the work, Deyanira Santiago for her help with animal care, Dr. John Klose and Dr. Mary Eaton for their assistance with the statistical analysis, and Robert Camerena for his photographic excellence. This work was supported by The Miami Project to Cure Paralysis, General Reinsurance, The Daniel Heuman Fund for Spinal Cord Injury, and NS26887.

Correspondence should be addressed to Scott R. Whittemore, Ph.D., The Miami Project, University of Miami School of Mcdicinc, 1600 NW 10th Avenue, R-48, Miami, FL 33136

aPresent address: National Tuberous Sclerosis Association, 8000 Corporate Drive, Suite 120, Landover, MD 20785.

Copyright $\mathbb{C} 1995$ Society for Neuroscience $0270-6474 / 95 / 156666-13 \$ 05.00 / 0$
}

tissue can integrate within the host brain and promote functional recovery in animal models of neurodegenerative disease (Perlow et al., 1979; Björklund and Stenevi, 1984; Gash et al., 1985; Segal et al., 1986; Lindvall et al., 1990). However, the use of fetal tissue for transplantation is complicated by logistical, immunological (Seiger, 1985; Widner and Brudin, 1988), and ethical (IIoffer and Olson, 1991) considerations. Several alternative cell types have been used in various transplantation paradigms including peripheral neurons (Freed et al., 1981), PC12 cells (Jaeger, 1985), and neuroblastoma cells (Gash et al., 1986; Kordower et al., 1987). However, these cells have not survived or have proved tumorigenic.

An alternative source of donor cells is genetically modified cells which can be engineered to secrete specific neurotransmitters or trophic factors to replace a lost or defective function (Gage et al., 1987, 1991). Genetically engineered cells have been transplanted after specific CNS lesions and in some cases ameliorate functional deficits (Horellou et al., 1990; Fisher et al., 1991). However, non-neuronal cells are limited in the extent to which they can integrate into the host neuronal circuitry. Several approaches to the development of immortalized neuroepithelial cell lines of CNS origin have been undertaken (Cepko, 1989; Gage et al., 1995; Whittemore et al., 1995). Results from transplanting such cell lines into the neonatal CNS suggest that immortalized pluripotent cell lines undergo both neuronal and glial differentiation that is dependent upon their location in the host tissue (Renfranz et al., 1991; Snyder et al., 1992; Gao and Hatten, 1994). Importantly, the neuronally differentiating cells sent projections to appropriate target sites and formed synapses with host-derived afferent fibers. A recent study demonstrates that engraftment of neural progenitor cells genetically engineered to secrete $\beta$-glucuronidase corrects the lysosomal storage disorder throughout the MPS VII mouse brain (Snyder et al., 1995), but this did not require the transplanted cells to differentiate with a neuronal phenotype. If immortalized CNS cell lines are to be used therapeutically as donor material to replace lost neurons, it may be advantageous for specific applications that they are restricted to a neuronal lineage in vivo. This is of importance in allogeneic grafts, as neuronal differentiation of CNS precursor cell lines results in down regulation of cell surface molecules necessary for recognition by cytotoxic T-lymphocytes (White et al., 1994).

The conditionally immortalized cell linc, RN33B, constitutively differentiates only with neuronal properties and does not demonstrate any non-neuronal phenotypes (Whittemore and White, 1993). In initial studies, Onifer et al. (1993) demonstrated 
that at two weeks posttransplantation into the adult rat hippocampus and spinal cord some RN33B cells morphologically differentiated with multiple neuritic processes. In the present study, we describe the developmental capacity of RN33B cells and their ability to respond to local microenvironmental cues following chronic transplantation into various regions of the adult and neonatal CNS.

\section{Materials and Methods}

Animals and chemicals. Timed-pregnant and adult female Lewis rats (175-200 gm) were purchased from Charles River Laboratories (Wilmington, MA). Rabbit polyclonal antisera to $\beta$-galactosidase ( $\beta$-gal) was obtained from 5 Prime-3 Prime. Inc. (Boulder, $\mathrm{CO}$ ); normal rabbit serum and Vectastain $\mathrm{ABC}$ kits were purchased from Vector Laboratories, Inc. (Burlingame, CA). Fluorescein di- $\beta$-D-galactopyranoside (FDG) was purchased from Molecular Probes, Inc. (Eugene, OR).

Cell culture. RN33B cells were grown at permissive temperature $\left(33^{\circ} \mathrm{C}\right)$ as described previously (Whittemore and White, 1993).

Preparation of $R N 33 B$ cells for transplantation. Prior to transplantation, undifferentiated RN33B cells were labeled in vitro by retrovirusmediated transfer of the $E$. coli Lac Z gene as described (Shimohama et al., 1989; Onifer et al., 1993). Cells were then incubated with FDG, and $\beta$-galactosidase immunoreactive ( $\beta$-gal-IR) RN33B cells enriched by fluorescent activated cell sorting (Nolan et al., 1988; Whittemore and White, 1993) and expanded. Using this method, over $80 \%$ of the RN33B cells were $\beta$-gal-positive as detected histochemically or immunohistochemically. When roughly $80 \%$ confluent, proliferating RN33B cells were washed with ice-cold PBS containing $0.5 \mathrm{~mm}$ ethylenediaminetetraacetic acid (EDTA), gently scraped in PBS containing EDTA, pelleted at $1500 \mathrm{rpm}$ for $3 \mathrm{~min}$, and resuspended in ice-cold, sterile Earl's balanced salt solution (EBSS). The pellets were washed twice and resuspended in EBSS at a density of 100,000 cells/ $\mu \mathrm{l}$ and stored on ice until use. Only cell suspensions demonstrating greater than $80 \%$ viability, as determined by Trypan blue exclusion, were used for transplantation. RN33B cells express RT1. $A^{\text {w/c }}$ haplotypes at the class I major histocompatibility complex (MHC) A locus (White et al., 1994) while Lewis rats are RT1.A' (Gill et al., 1987). Thus, these are allogeneic cell transplants. At the conclusion of the transplantation procedures, the viability of the suspended cells was reassessed and was always $\geq 70 \%$. For control transplants, a cell suspension of lysed (nonviable) RN33B cells of similar density was prepared by five repeated cycles of freezing and thawing.

Transplantation of RN33B cells into adult and neonatal brain. Adult rats were anesthetized by intraperitoneal injection of Equithesin ( 0.3 $\mathrm{ml} / 100 \mathrm{gm}$ body weight), prepared for surgery, and placed in a stereotaxic instrument (Narishige, Scientific Instument Lab.). Postnatal day 5 female Lewis rats were anesthetized by placing them on ice for $6 \mathrm{~min}$ and then maintaining hypothermia during the injection into one hemisphere using a stereotaxic instrument. After craniotomy, the exposed dura was cut over the transplantation site. Each animal received a unilateral injection of $1.0 \mu \mathrm{l}$ of RN33B cell suspension $\left(10^{5}\right.$ cells $)$ into the hippocampus, white matter, and cerebral cortex along one injection track in the right hemisphere. The stereotaxic coordinates used were initially determined from cresyl violet stained cryostat sections of agematched animals. The transplants were placed $1.7 \mathrm{~mm}$ lateral to midline, $2.1 \mathrm{~mm}$ posterior to bregma, and $2.0 \mathrm{~mm}$ below the dura. In adult rats, the transplantation site was $3.0 \mathrm{~mm}$ lateral to midline, $4.0 \mathrm{~mm}$ posterior to bregma, and $1.5-3.0 \mathrm{~mm}$ below the dura. Stereotaxic coordinates were derived according to Paxinos and Watson (1986). Cell suspensions were slowly injected with a $10 \mu \mathrm{l}$ Hamilton syringe over a period of 5 min. The needle was left in place for another $5 \mathrm{~min}$ and then slowly pulled up. Because of the backflow of some of the cell suspension while pulling up along the needle track, the precise number of RN33B cells injected into each site was difficult to establish. A total of 38 adults and 48 neonates were used (Table 1). No difference was observed between transplants into female rats and those into male rats in an earlier study (Onifer et al., 1993).

All surgical procedures were carried out in strict accordance with the Laboratory Animal Welfare Act, Guide for the Care and Use of Laboratory Animals (NIH, DHEW Pub. No. 78-23, Revised, 1978) only after review and approval by the Animal Care and Use Committee of the University of Miami School of Medicine.

$\beta$-Gal immunohistochemistry. After variable survival times $(1,2,5$,
Table 1. RN33B cell transplant recipients by age group and survival time posttransplantation; transplants containing $\beta$-gal immunoreactive cells were classified as positive

\begin{tabular}{lccc} 
Age & $\begin{array}{l}\text { Survival time } \\
\text { (weeks) }\end{array}$ & $\begin{array}{c}\text { Total \# } \\
\text { of rats }\end{array}$ & $\begin{array}{l}\text { \# of } \\
\text { positive } \\
\text { trans- } \\
\text { plants }\end{array}$ \\
\hline Age & 2 & 9 & 9 \\
& 5 & 8 & 8 \\
& 8 & 10 & 6 \\
Total & 16 & 8 & 3 \\
Neonate & 24 & 3 & 1 \\
& $2-24$ & 38 & 28 \\
& 2 & 11 & 10 \\
& 5 & 12 & 8 \\
Total & 8 & 13 & 9 \\
& 16 & 10 & 4 \\
& 24 & 2 & 2 \\
\hline
\end{tabular}

8 , 16, and 24 weeks) following RN33B cell transplantation, animals were deeply anesthetized, and then transcardially perfused with $\mathrm{Ca}^{2+}$ free Tyrode's solution followed by a modified Zamboni's fixative containing $4 \%$ paraformaldehyde and $10 \%$ picric acid in PBS, pH 6.9. Brains were removed, postfixed for $90 \mathrm{~min}$ in the same fixative and kept overnight at $4^{\circ} \mathrm{C}$ in PBS ( $\mathrm{pH}$ 7.4). Brains were blocked for coronal sectioning through the transplanted region. Serial $50 \mu \mathrm{m}$ sections were cut on a vibratome and stored at $4^{\circ} \mathrm{C}$ in PBS until further processing. Floating sections were processed for $\beta$-gal immunoreactivity as previously described (Onifer et al., 1993).

Quantitative analysis of the morphological differentiation of trans. planted RN33B cells. Every sixth $50 \mu \mathrm{m}$ vibratome section through the transplant site ( 12 sections per animal) was processed for $\beta$-gal immunohistochemistry. Transplanted $\beta$-gal-positive RN33B cells were quantified using an MAGE-1 image analysis system (Universal Imaging Corp., West Chester, PA). Sections were observed by light microscopy at low magnification $(50 \times)$ to localize the the integration site of the transplant (neocortex, hippocampus, or white matter). A grid, covering $1.98 \mathrm{~mm}^{2}$, was overlaid on the low magnification image of the region of interest. Each square was analyzed at higher magnification $(200 \times)$ to count $\beta$-gal-IR cells and assess the degree of morphological differentiation of detected cells in terms of shape or the cell body, the number of processes that these cells extended, and the pattern and orientation of these processes. Only labeled cells where a nucleus and a cytoplasm could be seen were included in the quantitative analysis. Transplanted RN33B cells with sheath-like somas in which a nucleus and cytoplasm, but no processes, were seen were classified as undifferentiated. Cells with an ovoid or spindle-shaped cell body and $\leq 2$ processes were classified as bipolar, while cells with $\geq 3$ processes and cell bodies with variable morphologies were classified as multipolar. $\beta$-gal-IR multipolar cells in the neocortex were classified as pyramidal cells if they had triangular or ovoid cell bodies and a long apical neuritic process extending towards the apical surface and two long basal processes or as stellate cells if they had polymorphic cell bodies and four or more long processes extending radially from the cell body. The criteria used to categorize the labeled cells were based on earlier descriptions of cortical cells stained by the method of Golgi (Ramon y Cajal, 1988). In the hippocampus, $\beta$-gal-IR cells were classified as CA3 pyramidal cells if they were located in the pyramidal cell layer of the CA3 region, had large, angular cell bodies with abundant cytoplasm that tapered into one or two apical processes, a small number of wide basal processes and had appropriate structural polarity. Cells were characterized as CA1 pyramidal cells if they were located in the pyramidal layer of the CA1 region, had appropriate structural polarity, had small cell bodies, hut otherwise had charateristics similar to CA3 pyramidal cells. $\beta$-gal-IR cells located in the granular cell layer that had small round or ovoid cell bodies, unipolar neuritic arbors, and lacked basal processes were classified as granular cells. The classification criteria used are based on 


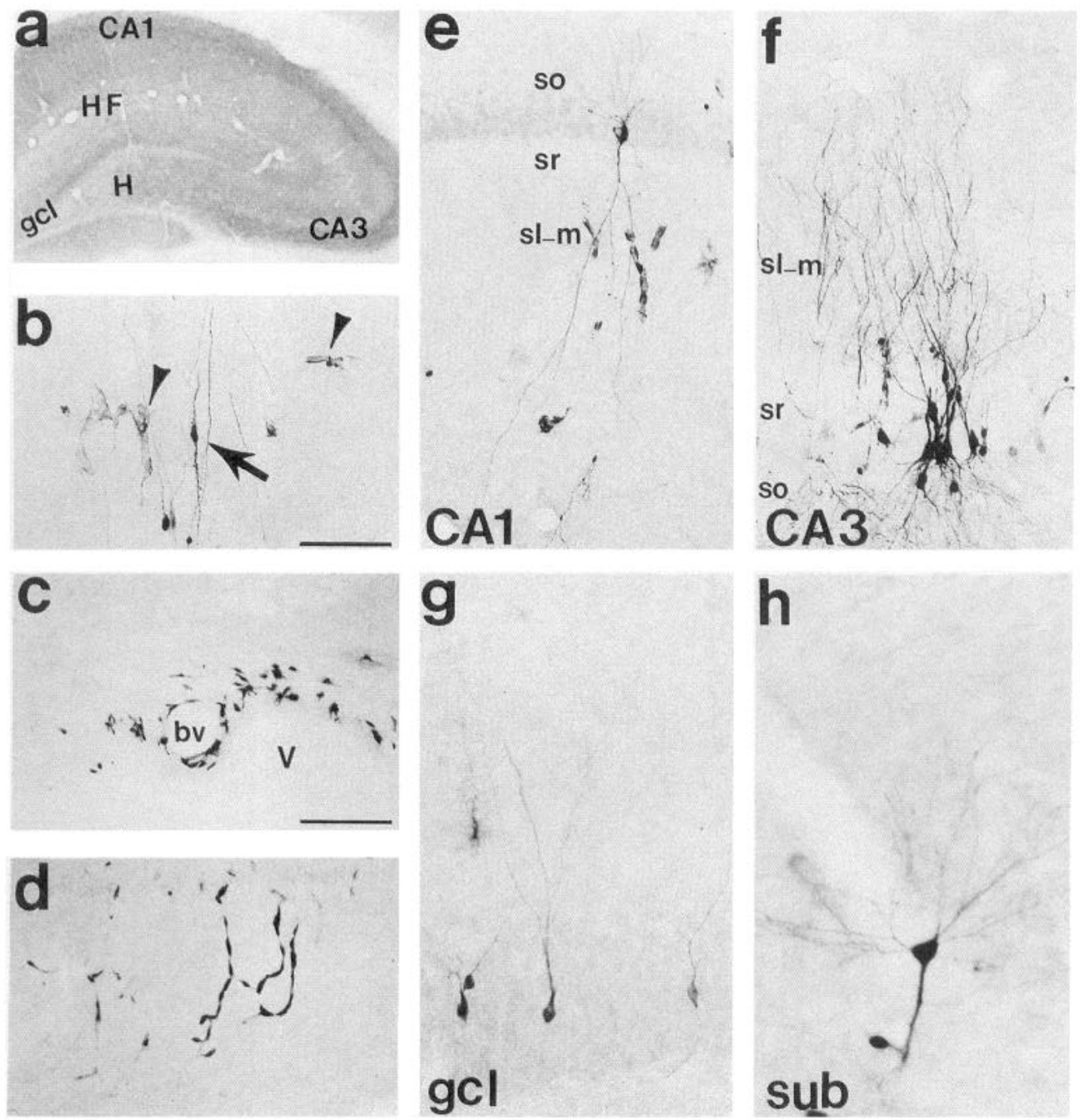

Figure 1. Variable morphologies of $\beta$-gal-IR RN33B cells transplanted into the hippocampal formation. Bright-field photomicrographs of $\beta$-galIR RN33B cells in coronal sections of the hippocampus. $a$, Photomicrograph of the rat hippocampal formation. Abbreviations: fields CA1-3 of Ammon's horn (CAl-CA3), granular cell layer $(\mathrm{gcl})$, hilar region $(H)$, and the hippocampal fissure $(H F)$. $b$, A bipolar $\beta$-gal-IR RN33B cell (arrow) in the stratum lacunosum-moleculare, and undifferentiated $\beta$-gal-IR cells (arrowheads). $c$, Undifferentiated RN33B cells surrounding a blood vessel $(b v)$ and lining the lateral ventricle $(V) . d$, Undifferentiated RN33B cells in the stratum lacunosum-moleculare above the hippocampal fissure. $\beta$-galIR RN33B cells with their cell bodies embedded in the pyramidal layer of CA1 $(e)$ and CA3 $(f)$ had somewhat ovoid or angular cell somas with abundant cytoplasm that tapered into an apical process extending through the stratum radiatum $(s r)$ and into the stratum lacunosum moleculare (sl$m$ ). In the lacunosum moleculare layer, many secondary and tertiary branches are observed. The basal processes exit from several places along the base of the perikaryon into the stratum oriens $(s r-o) . g, \beta$-gal-IR RN33B cells with ovoid cell bodies embedded in the gcl, with processes extending from the apical end of the cell bodies. At the base of the cell body, one cell has a fine process extending toward the hilar region. $h$, $\beta$-gal-IR RN33B cell body embedded in the pyramidal layer of the subiculum $(s u b)$, extending an apical process and two basal processes with multiple branches. Scale bars: $b, g, h, 50 \mu \mathrm{m} ; c-f, 100 \mu \mathrm{m}$. The age of host and the intervals between transplants and histology are adult and 5 weeks in $b$ and $d$; neonate and 2 weeks in $c$ and $e$; adult and 8 weeks in $f$, neonate and 16 weeks in $g$; neonate and 5 weeks in $h$.

detailed descriptions of Golgi-impregnated hippocampal neurons in situ (Bayer, 1980; Gahwilar, 1984; Frotscher et al., 1988).

An estimate of the number and extent of differentiation of the transplanted RN33B cells was made by counting all $\beta$-gal-IR cells in all sections processed per animal, and categorizing these cells into the different cell types by location, morphology, and structural polarity. These data were used to calculate the percent of the total cells detected that assumed differentiated neuronal morphologies. An exact count of the number of surviving RN33B cells can not be made as not all transplanted RN33B cells were $\beta$-gal-IR prior to transplantation $(\approx 80 \%$ expressed $\beta$-gal immunoreactivity) and down regulation of $\beta$-galactosidase expression from viral LTRs in vivo may occur (St. Louis and Verma, 1988; Palmer et al., 1991; Onifer et al., 1993). However, similar cell suspensions were used for all animals and these quantitative data can be used as estimates to compare the effect of the age of the host and the survival time posttransplantation on the number of detected RN33B cells and the percentage of differentiated cells.

\section{Results}

Survival of transplanted RN33B cells

Following transplantation into adult and neonatal CNS, surviving RN33B cells were detected using $\beta$-gal immunohistochemistry. Even though the cell concentration, volume transplanted, and coordinates of transplant were kept constant across experiments, the number and position of the transplanted RN33B cells varied from animal to animal. RN33B cell transplants were found in $100 \%$ of adult rats that survived for up to 2 weeks. At longer posttransplant survival intervals, 4-24 weeks, the efficiency of successful transplantation ranged from $33-100 \%$ (Table 1). RN33B cell transplants were found in $90 \%$ of the neonates that survived for up to 2 weeks posttransplantation. At 

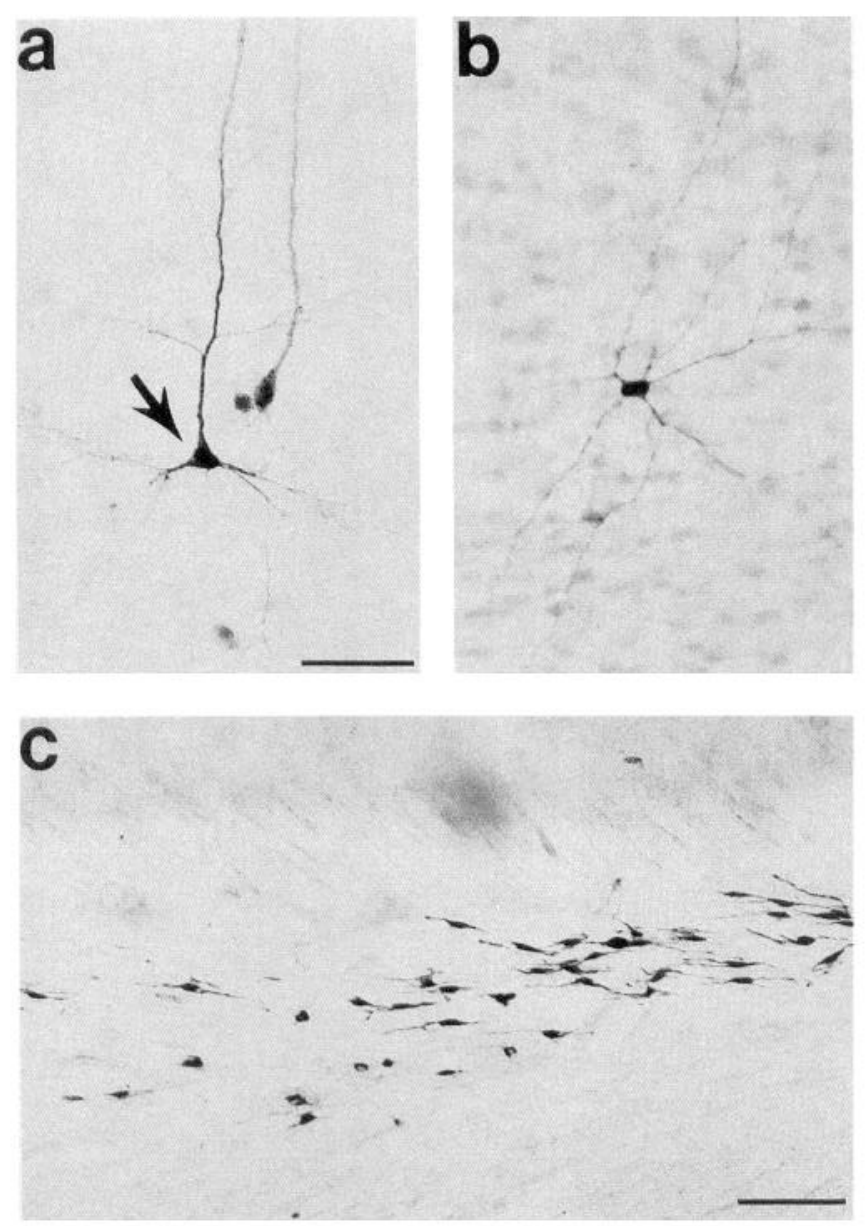

Figure 2. Variable morphologies of $\beta$-gal-IR RN33B cells transplanted into the cerebral cortex. Bright-field photomicrograph of $\beta$-gal-IR RN33B cells in a coronal section of the cerebral cortex, $a, \beta$-gal-IR RN33B cell with a pyramidal cell body (arrow), a large apical process extending towards the pial surface and branching basal processes. A fine process can be seen extending from the basal surface towards the white matter. A $\beta$-gal-IR RN33B cell with an ovoid cell body and an apical process can be also seen. $b, \mathrm{~A}$ RN33B cell with a polygonal cell body and five divergent branched neuritic processes. $c$, Bipolar RN33B cells in the corpus callosum. Scale bars: $a$ and $b, 50 \mu \mathrm{m} ; c, 100 \mu \mathrm{m}$. The age of host and the intervals between transplant and histology are adult and 2 weeks in $a$; neonate and 16 weeks in $b$; neonate and 2 weeks in $c$.

survival intervals of 5-16 weeks, the efficiency of successful transplantation ranged from 40-67\%. RN33B cells can survive up to 6 months posttransplantation in nonimmunosuppressed, histoincompatible adult and neonatal rat hosts (see Fig. $4 a, b$ ).

\section{Morphological classification of transplanted $\beta$-gal-IR RN33B cells}

Nearly all of the transplanted, RN33B $\beta$-gal-IR cells were found in the neocortex, subadjacent white matter, and hippocampus, although a few cells were also detected in the diencephalon, in the lining of the lateral ventricles, or within the meninges overlying the cortical injection site. In the hippocampal formation, $\beta$-gal-IR cells assumed variable morphologies depending on their location within the cellular layers of the hippocampus or hippocampal parenchyma (Fig. 1). The cells varied in size and shape of the cell soma and pattern of neuritic outgrowth. At early time points, undifferentiated $\beta$-gal-IR cells with sheath- like cell somas and no processes were found within all regions and layers of the hippocampus (Fig. 1d) and around blood vessels (Fig. 1c). Other $\beta$-gal-IR cells within the lacunosum molecular layer, radiatum layer, and dentate gyrus had bipolar morphologies (Fig. 1b). $\beta$-gal-IR cells located in the hippocampal fissure and lining the ventricles assumed both undifferentiated and bipolar morphologies. Most of the $\beta$-gal-IR cells whose somata were embedded in the pyramidal layer of CA1 (Fig. 1e) or CA3 (Fig. $1 f$ ) had somewhat angular cell somas with abundant cytoplasm that tapered into an apical process extending through the stratum radiatum and into the stratum lacunosum molecular; many secondary and tertiary branches were seen. In addition, basal processes exited from several places along the base of the perikaryon and repeatedly branched in the stratum oriens. In the granular cell layer of the dentate gyrus, $\beta$-gal-IR cells displayed a characteristic monopolar, conically shaped field of processes extending from the apical end of an ovoid cell body to fan out in the host molecular region (Fig. $1 g$ ), which is the dendritic field of the dentate gyrus granular neurons. In the subiculum, some $\beta$-gal-IR cells also had pyramidal morphologies (Fig $1 h$ ).

In the cerebral cortex, $\beta$-gal-IR cells that assumed neuronal phenotypes were classified as pyramidal-like (Fig. $2 a$ ) or stellate-like (Fig. $2 b$ ) cells. Some cortical $\beta$-gal-IR cells had ovoid or pyramidal cell bodies, a large apical process extending towards the pial surface and branching basilar processes. In some cells (arrow in Fig. $2 a$ ), a small caliber process extended from the basal surface towards the white matter. These processes may be axons, since the axons of pyramidal neurons have a smaller diameter than their dendrites. Such $\beta$-gal-IR RN33B cells were dispersed through layers II-VI of the cerebral cortex. Other $\beta$-gal-IR cells were polygonal or stellate in form and had four or more divergent branched varicose processes extending in all directions (Fig. $2 b$ ). These cells were few in number, and were seen in layer I underneath the pial surface or in layer VI above the corpus callosum. In white matter, at all intervals posttransplantation, $\beta$-gal-IR cells were either morphologically undifferentiated or bipolar, with a spindle-shaped cell body and unbranched short processes extending from opposite sides of the cell soma (Fig. $2 c$ ). No $\beta$-gal-IR cells were detected in animals that received lysed RN33B cells (data not shown).

\section{Time course of survival and differentiation of $R N 33 B$ cell transplants in adult hippocampus}

In the hippocampal formation, $\beta$-gal-IR RN33B cells were found within all regions and layers of the hippocampus spanning 1.8$2.5 \mathrm{~mm}$ (anterior-posterior dimension) and 0.8-1.5 mm (mediallateral dimension) from the injection site. At 1 week posttransplantation, the majority of $\beta$-gal-IR cells were aligned along the needle track (Fig. $3 a$ ) and assumed undifferentiated morphologies. Some of the $\beta$-gal-IR cells located in field CA3 exhibited some morphological differentiation with ovoid cell bodies and an apical process (arrows in Fig. $3 b$ ). At 8 weeks posttransplantation, many of the detected $\beta$-gal-IR cells were located in the hilar and CA3 region. These cells were morphologically differentiated with elaborate processes and extensive branching (Figs. $3 c, d)$. $\beta$-gal-IR cells were still detected at 24 weeks posttransplantation (Fig. $4 a$ ). The $\beta$-gal-IR cells in CA3 pyramidal layer had pyramidal cell bodies, extensive apical processes extending in the stratum radiatum toward stratum lacunosum-moleculare, and basal processes descending into the stratum oriens. 

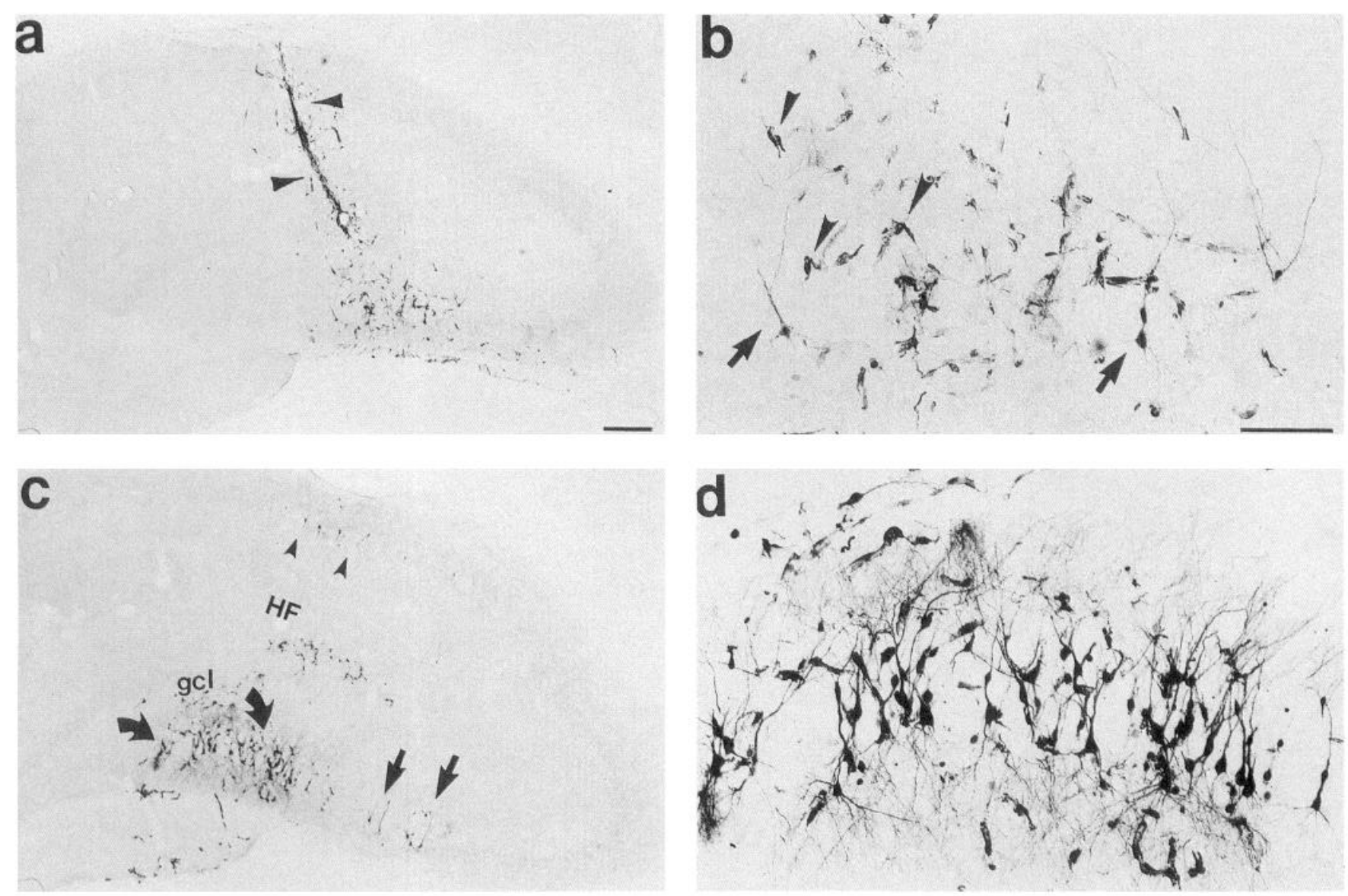

Figure 3. $\beta$-gal-IR RN33B cells in the adult hippocampus $1(a, b)$ and $8(c, d)$ weeks posttransplantation. $a$, Low-power view of the $\beta$-gal-IR RN33B transplant at 1 week posttransplantation. Many labeled cells are aligned along the needle track (arrowheads) and have undifferentiated morphologies. $b$, Higher magnification of $\beta$-gal-IR RN33B cells located in the CA3 pyramidal layer; some cells have ovoid cell bodies and extend some apical processes (arrows). Other $\beta$-gal-IR cells have undifferentiated morphologies (arrowheads). $c$, Low-power view of $\beta$-gal-IR RN33B cells at 8 weeks posttransplantation. Most cells have differentiated morphologies. Some $\beta$-gal-IR RN33B cells are located in the CA1 pyramidal cell layer (arrowheads) and extend both apical and basal processes. Most of the cells are located in the hilar region (curved arrows) and send out extensive processes. Some $\beta$-gal-IR RN33B cells are located in the CA3 pyramidal cell layer (straight arrows). Some undifferentiated cells are located above the granular cell layer $(\mathrm{gcl})$ and below the hippocampal fissure $(H F)$. $d$, Higher magnification showing $\beta$-gal-IR RN33B cells located in the hilar and CA3 regions. These cells are morphologically differentiated with elaborate processes and extensive neuritic branching, exhibiting structural polarity appropriate for neurons of that region. Scale bars: $a$ and $c, 200 \mu \mathrm{m} ; b$ and $d, 100 \mu \mathrm{m}$.

\section{Time course of survival and differentiation of RN33B cell transplants in adult cerebral cortex}

$\beta$-gal-IR RN33B cells were dispersed without order throughout the entire thickness of the neocortex (Fig. 5). At 2 weeks posttransplantation, the majority of the detected RN33B cells were undifferentiated (Fig. 5a,b). However, a few $\beta$-gal-IR cells had morphologies similar to those of endogenous pyramidal and stellate cortical neurons (arrows in Fig. 5a-f). After survival intervals of 5 (Fig. $5 c, d$ ) and 16 (Fig. $5 e, f$ ) weeks, some of the transplanted RN33B cells remained undifferentiated (arrowheads in Fig. $5 c, e)$ or assumed bipolar morphologies. Other $\beta$-gal-IR RN33B cells differentiated with morphologies similar to those of endogenous pyramidal cortical neurons (Figs. $5 d, f$ ). Their ovoid or pyramidal cell bodies ranged from 7 to $16 \mu \mathrm{m}$ in diameter, and they had thick apical processes extending towards the pial surface of the brain. Shorter branched, basal processes extended horizontally (Fig. $5 c-f$ ). At 5 weeks posttransplantation, more $\beta$-gal-IR cells were differentiated than observed at 2 weeks, but the total number of cells detected appeared not to change. Similar results were seen, at 8 and 16 weeks posttransplantation.

\section{Quantitative analysis of RN33B cell transplants in the adult CNS}

Morphological criteria described above and illustrated in Figures 1 and 2 were used to classify $\beta$-gal-IR RN33B cells in the cerebral cortex, hippocampus, and white matter into various cell types. Animals were chosen for quantitation based on the following criteria: (1) evidence of $\beta$-gal-IR cells in both hippocampus and cerebral cortex, and (2) that the entire transplant was contained within the sectioned region. To illustrate the quantitation, Table 2 presents data from a representative neonatal animal for each posttransplantation survival interval. It shows that RN33B cells were counted and classified as different cell types depending on the location and the cellular morphology in each region. In adults the total number of $\beta$-gal-IR cells in the neocortex and hippocampus did not change with longer survival times (up to 16 weeks, Fig. $6 a$ ). While there was a trend towards an increased percentage of differentiated $\beta$-gal-IR cells in the cerebral cortex and hippocampus with longer survival times (Fig. 6b), these differences were not statistically significant. The percent of maximal morphological differentiation at 8 weeks 

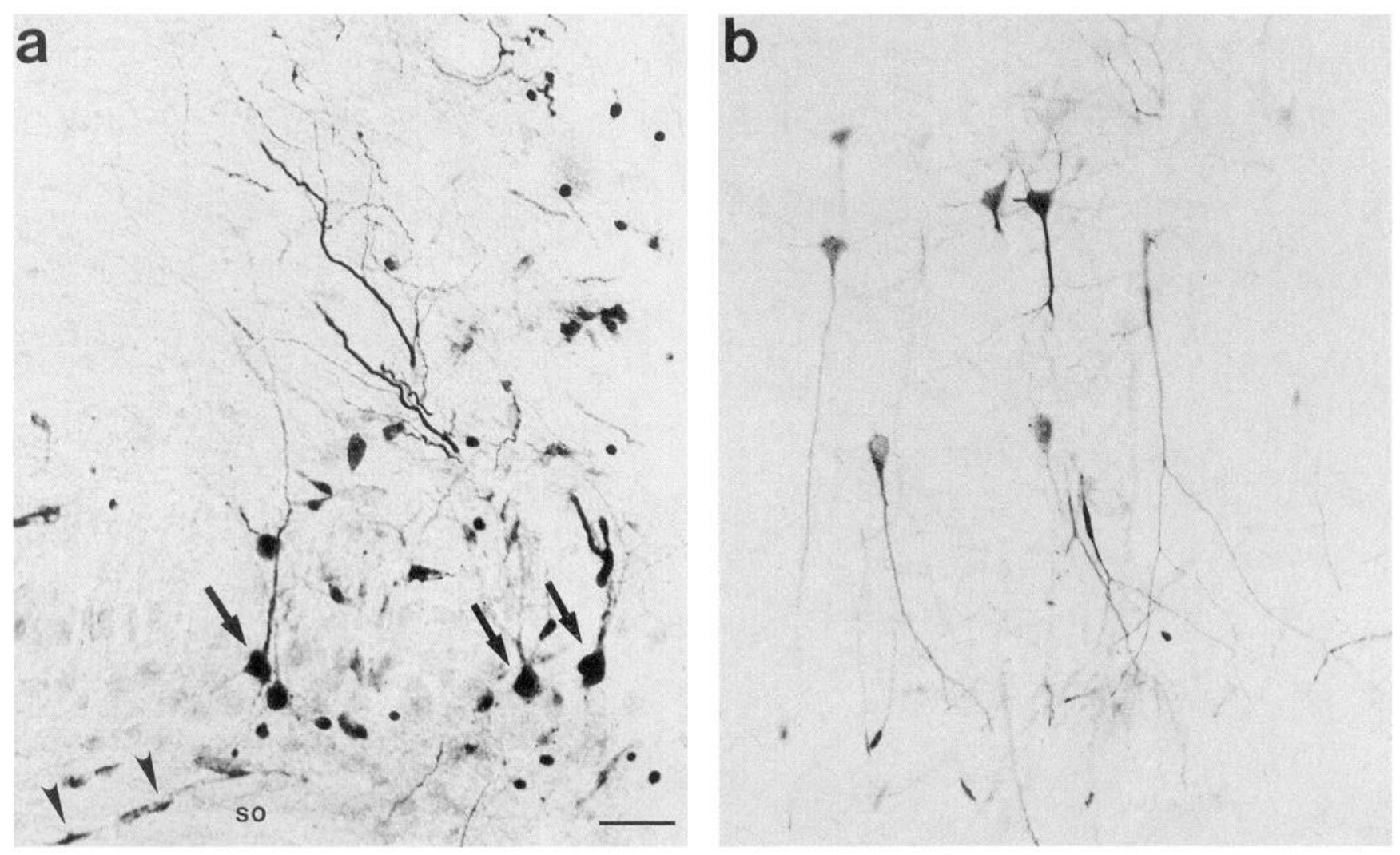

Figure 4. $\quad \beta$-gal-RN33B cells in the adult and neonatal hippocampus at 24 weeks posttransplantation. $a$, In adults, $\beta$-gal-IR RN33B cells located in the pyramidal cell layer of the CA3 field (arrows) are multipolar with elaborate apical processes and extensive branching. Bipolar $\beta$-gal-IR RN33B cells are seen in the stratum oriens (so, arrowheads). $b$, In neonates, $\beta$-gal-IR RN33B cells located in the subiculum are pyramidal with elaborate apical and basal processes, and structural polarity appropriate for pyramidal cells of this region. Scale bar: $50 \mu \mathrm{m}$ for $a$ and $b$.

posttransplantation was roughly $22 \%$ of the cells detected in the cerebral cortex and $13 \%$ of those in the hippocampus.

\section{Time course of survival and differentiation of $R N 33 B$ cell transplants in neonatal hippocampus}

In neonates, as in adults, $\beta$-gal-IR cells were found within all regions and layers of the hippocamus spanning 2.4-3.6 mm (anterior-posterior dimension) and 1.1-2.0 mm (medial-lateral dimension). Two weeks posttransplantation, many $\beta$-gal-positive RN33B cells were detected in the neonatal hippocampal formation (Fig. 7a,b). Some $\beta$-gal-IR cells in the pyramidal layers of CA3 (arrows in Fig. 7a) and CA1 (arrowheads in Fig. 7a) fields had ovoid cell bodies and extended apical processes into stratum radiatum and towards stratum moleculare, with basal processes into the stratum oriens. However, the majority of $\beta$-gal-IR cells were undifferentiated. At 5 weeks posttransplantation, fewer $\beta$-gal-positive cells were detected (Fig. $7 c, d$ ), but more were morphologically differentiated. Figure $7 d$ shows an example of cells in the CA3 field. Note the morphological differences between $\beta$-gal-IR cells that were located in the pyramidal cell layer where most of the cells assumed pyramidal morphologies, and $\beta$-gal-IR cells that were located above or below the pyramidal cell layer. These latter cells remained undifferentiated or assumed bipolar morphologies. By 16 weeks posttransplantation, most $\beta$-gal-IR cells assumed phenotypes similar to neurons at the integration site (Fig. $7 e, f$ ). $\beta$-gal-IR cells with cell bodies in the granular cell layer were ovoid with several processes extending into the host molecular region (small arrows in Fig. 7e). Other $\beta$-gal-IR cells were located in the hilus and
CA3 field. Figure $7 f$ shows a higher magnification of polymorphic $\beta$-gal-IR cells with multiple processes in the hilus (large arrows in Fig. 7e) and cells in the pyramidal layer of the CA3 field with ovoid cell bodies, apical and basal processes, and structural polarity appropriate for pyramidal cells of this region (arrowheads in Fig. 7e). $\beta$-gal-IR cells were still detected at 24 weeks posttransplantation (Fig. $4 b$ ).

Time course of survival and differentiation of $R N 33 B$ cell transplants in neonatal cerebral cortex

In the cerebral cortex of neonates, the temporal progression of RN33B cell differentiation was similar to that seen in the hippocampus. At 2 weeks posttransplantation, a large number of $\beta$-gal-IR RN33B cells were detected (Fig. $8 a, b$ ). Some $\beta$-gal-IR cells had morphologically differentiated to resemble cortical pyramidal neurons with long apical processes extending towards the pial surface (Fig. $8 b$ ), but the majority were undifferentiated. At 5 weeks posttransplantation, fewer $\beta$-gal-IR cells were found (Fig. $8 c, d$ ), but many more were differentiated. A cluster of $\beta$-gal-IR cells located in the deeper layers (IV-VI) of the neocortex had pyramidal cell bodies with diameters of 10-16 $\mu \mathrm{m}$ and extensive branched processes (Fig. 8d) resembling endogenous pyramidal cortical neurons. By 16 weeks posttransplantation, most $\beta$-gal-IR cells had differentiated phenotypes (Figs. $8 e, f)$.

\section{Quantitative analysis of $\beta$-gal-IR RN33B cell transplants in the neonatal CNS}

Figure $9 a$ shows that the total number of $\beta$-gal-IR cells in neonatal hosts significantly decreased with longer survival times. 

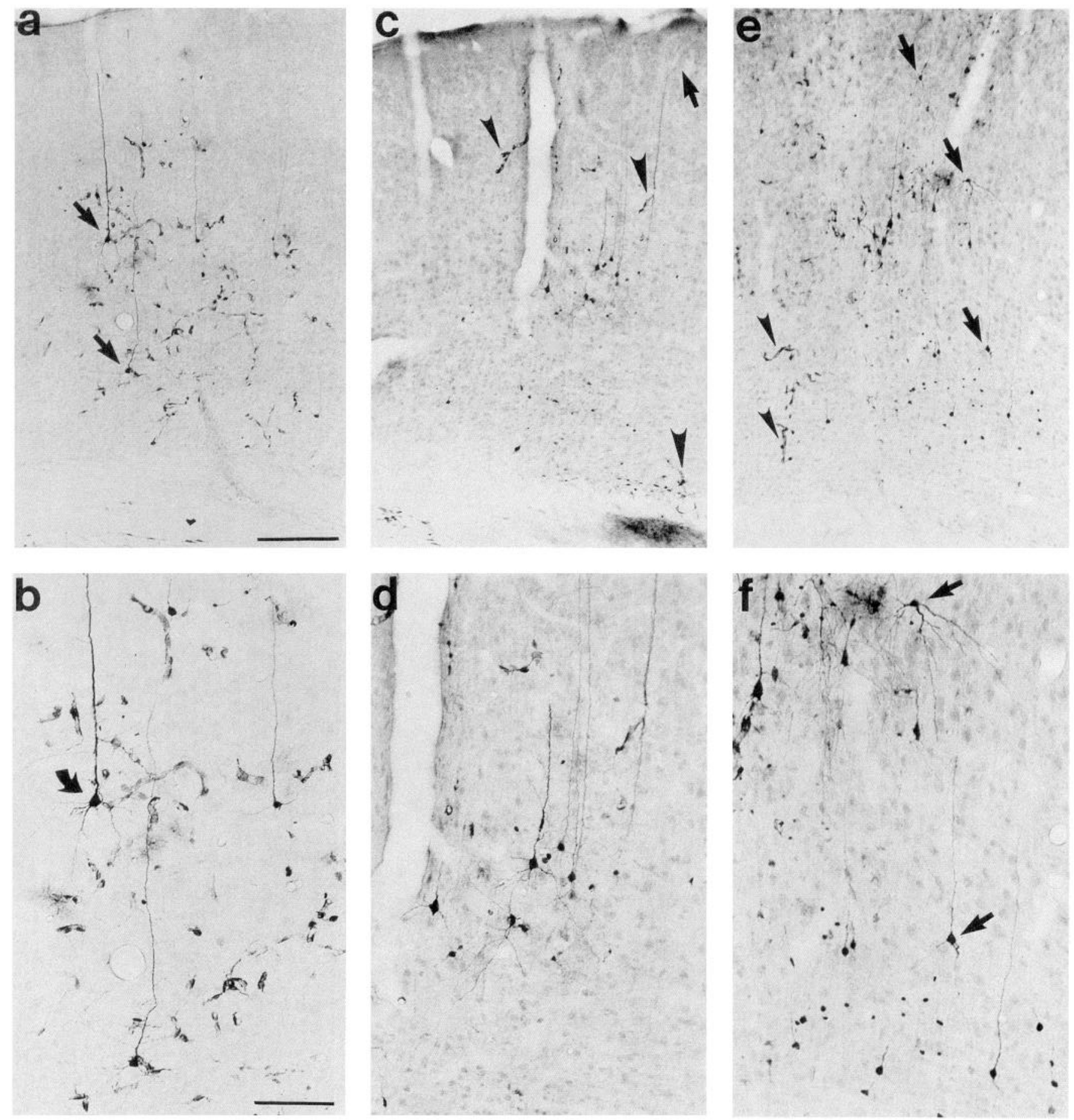

Figure 5. Temporal progression of RN33B differentiation in the adult cerebral cortex. $\beta$-gal-IR RN33B cell transplants in coronal sections of adult occipital cerebral cortex at $2(a, b), 5(c, d)$, and $16(e, f)$ weeks posttransplantation. $b, d$, and $f$ are higher magnification photomicrographs of regions of the fields shown in $a, c$, and $e$, respectively. At 2 weeks posttransplantation $(a, b)$ the majority of $\beta$-gal-IR RN33B cells are undifferentiated. A few $\beta$-gal-IR RN33B cells extended large caliber apical process and extensive basal processes (arrows in $a$ ), similar to endogenous cortical pyramidal neurons. One of the cells (curved arrow) had a fine axon-like process extending towards the white matter. At 5 weeks, many $\beta$-gal-IR RN33B cells were differentiated with morphologies similar to those of medium-sized pyramidal neurons $(c, d)$. Note the extensive process outgrowth extending both distally and apically towards the pial surface. The arrow in $c$ indicates the terminal arborization in the plexiform layer of processes from an $\beta$-gal-IR RN33B cell whose cell body is in another plane of focus. Some undifferentiated cells are seen (arrowheads in $c$ ) and some cells are observed in close proximity to blood vessels. At 16 weeks $(e, f)$, more differentiated $\beta$-gal-IR RN33B cells are seen dispersed throughout the thickness of the cerebral cortex (arrows in $e$ and $f$ ). Some $\beta$-gal-IR RN33B cells remained undifferentiated (arrowheads in $e$ ). Scale bars: $a, c$ and $e, 200 \mu \mathrm{m} ; b, d$, and $f, 100 \mu \mathrm{m}$. 


\begin{tabular}{|c|c|c|c|c|c|}
\hline \multirow[b]{2}{*}{ Region } & & \multicolumn{4}{|c|}{ Animal \# } \\
\hline & & $\begin{array}{l}\text { HCTP2 } \\
\mathrm{F}\end{array}$ & $\begin{array}{l}\text { HCTP5 } \\
\mathrm{F}\end{array}$ & $\begin{array}{l}\text { HCTP8 } \\
\mathrm{H}\end{array}$ & $\begin{array}{l}\text { HCTP16 } \\
\mathrm{B}\end{array}$ \\
\hline \multirow[t]{6}{*}{ Cortex } & Pyramidal cell & 73 & 312 & 61 & 279 \\
\hline & Stellate cell & 7 & 30 & 9 & 60 \\
\hline & Bipolar & 25 & 21 & 5 & 99 \\
\hline & Around vessels & 14 & 34 & 0 & 11 \\
\hline & Undefined & 13 & 14 & 0 & 25 \\
\hline & Undifferentiated & 495 & 190 & 14 & 205 \\
\hline \multirow{9}{*}{ Hippocampus } & CA3 pyram. cell & 115 & 70 & 15 & 31 \\
\hline & CA1 pyram. cell & 45 & 61 & 10 & 15 \\
\hline & Granular cell & 1 & 57 & 21 & 19 \\
\hline & Subiculum cell & 0 & 0 & 10 & 22 \\
\hline & Hilar region & 0 & 60 & 67 & 123 \\
\hline & Bipolar & 171 & 111 & 106 & 86 \\
\hline & Around vessels & 141 & 54 & 14 & 86 \\
\hline & Undefined & 147 & 238 & 58 & 70 \\
\hline & Undifferentiated & 1575 & 1082 & 551 & 98 \\
\hline \multirow[t]{2}{*}{ White matter } & Bipolar & 1880 & 645 & 191 & 97 \\
\hline & Undifferentiated & 3483 & 640 & 364 & 37 \\
\hline Total & & 8185 & 3630 & 1496 & 1295 \\
\hline
\end{tabular}

Each column illustrates a representative neonatal animal for each survival interval. RN33B cells detected were counted and classified into different cell types depending on location of integration and morphology of cells in each region. Animal \# abbreviations: hippocampal cortical transplant in postnatal rat (HCTP); the number indicates the survival interval $(2,5,8$, or 16 weeks), and the last letter indicates the animal in a series of transplants (A-I).

Posthoc analysis showed that all time points differed significantly with the exception of 8 and 16 weeks. At 2 weeks posttransplantation 59\% of transplanted cells were detected. By 5 weeks $46 \%$ of the initial cells detected at 2 weeks remained, while only $13 \%$ of those detected at 2 weeks were observed 16 weeks after transplantation. In contrast, the percent of differentiated cells significantly increased with longer posttransplant survival times in the cerebral cortex and in the hippocampus (Fig. $9 c$ ), so that at 16 weeks $68 \%$ of the remaining RN33B cells exhibited a differentiated phenotype in the cerebral cortex and $63 \%$ in the hippocampus. However, the total number of differentiated RN33B cells in the cerebral cortex and the hippocampus at various survival times was not significantly different (Fig. $9 b$ ).

\section{Discussion}

Transplanted RN33B cell assume complex and variable neuronal phenotypes in the neocortex and hippocampal formation of adult and neonatal rat hosts. As observed in vitro (Whittemore and White, 1993), RN33B cells differentiate in vivo only along a neuronal phenotype. Optimal morphological differentiation into region-specific neuronal phenotypes was seen only following transplantation into the CNS. The classifications of RN33B cells are based on morphological criteria comparable to those described in earlier studies of Golgi-impregnated neurons. RN33B cells in different neuroanatomical sites assumed morphologies characteristic of endogenous neurons at the integration site or remained undifferentiated. In the hippocampus, depending on the cell layer in which RN33B cells were located, some cells assumed morphological characteristics similar to those of endogenous CA1, CA3, and subiculum pyramidal neurons and granule cell neurons in terms of the shapes of their cell bodies
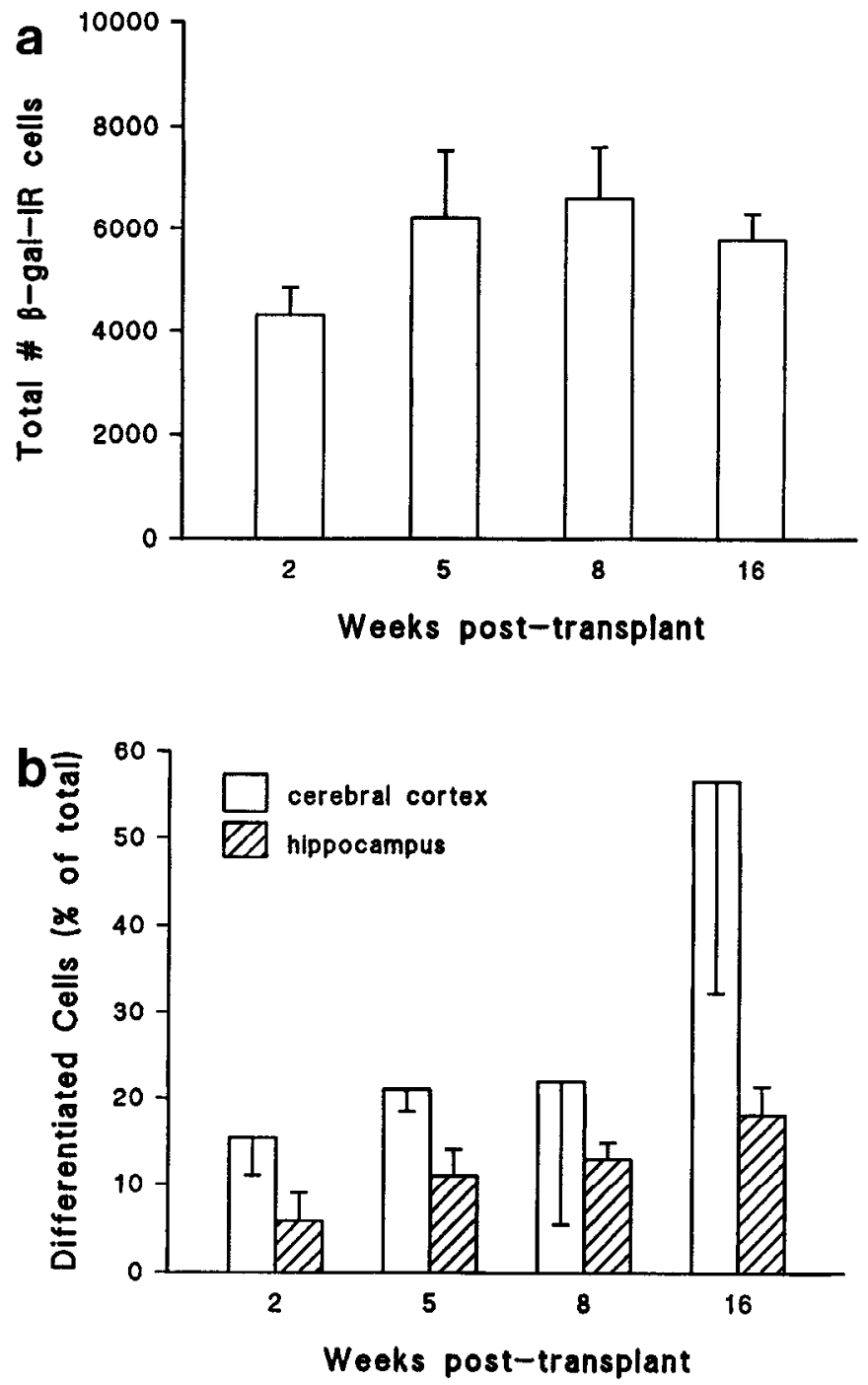

Figure 6. Quantitation of surviving, $\beta$-gal-IR RN33B cell in adult CNS. $a$, Counts of total numbers of $\beta$-gal-IR cells after variable survival intervals demonstrate that the total number of RN33B cells did not change with longer survival times (ANOVA, $\mathrm{df}=3,11, F=0.921, p$ $=0.462$ ). Each bar gives the mean \pm SEM for four animals except at 16 weeks which represents three animals. $b$, The percentage of differentiated $\beta$-gal-IR RN33B cells in the cerebral cortex and hippocampus increased with longer survival times. Statistical analysis showed that these increases are not significant (ANOVA, $\mathrm{df}=3,11, F=1.746$ and $2.842, p=0.215$ and 0.086 in the cerebral cortex and hippocampus, respectively).

and the number, pattern, and orientation of neuritic processes and their structural polarity (Bayer, 1980; Gahwilar, 1984; Frotscher et al., 1988). In the cerebral cortex, the morphologies of differentiated RN33B cells were consistent with thosc of cortical pyramidal neurons and polygonal cells of the first cortical layer and polymorphic cells of the deep layer of Golgi (Ramon y Cajal, 1988). In white matter, RN33B cells remained undifferentiated or became spindle-shaped, bipolar cells. Double staining for GFAP and X-gal indicated that transplanted RN33B cells did not differentiate to an astrocytic phenotype. Moreover, recent ultrastructural results have detected synapses on $\beta$-gal-IR processes in both the cerebral cortex and hippocampus (L. S. Shihabuddin, M. B. Bunge, V. R. Holets, and S. R. Whittemore, unpublished observations), consistent with a differentiated neu- 

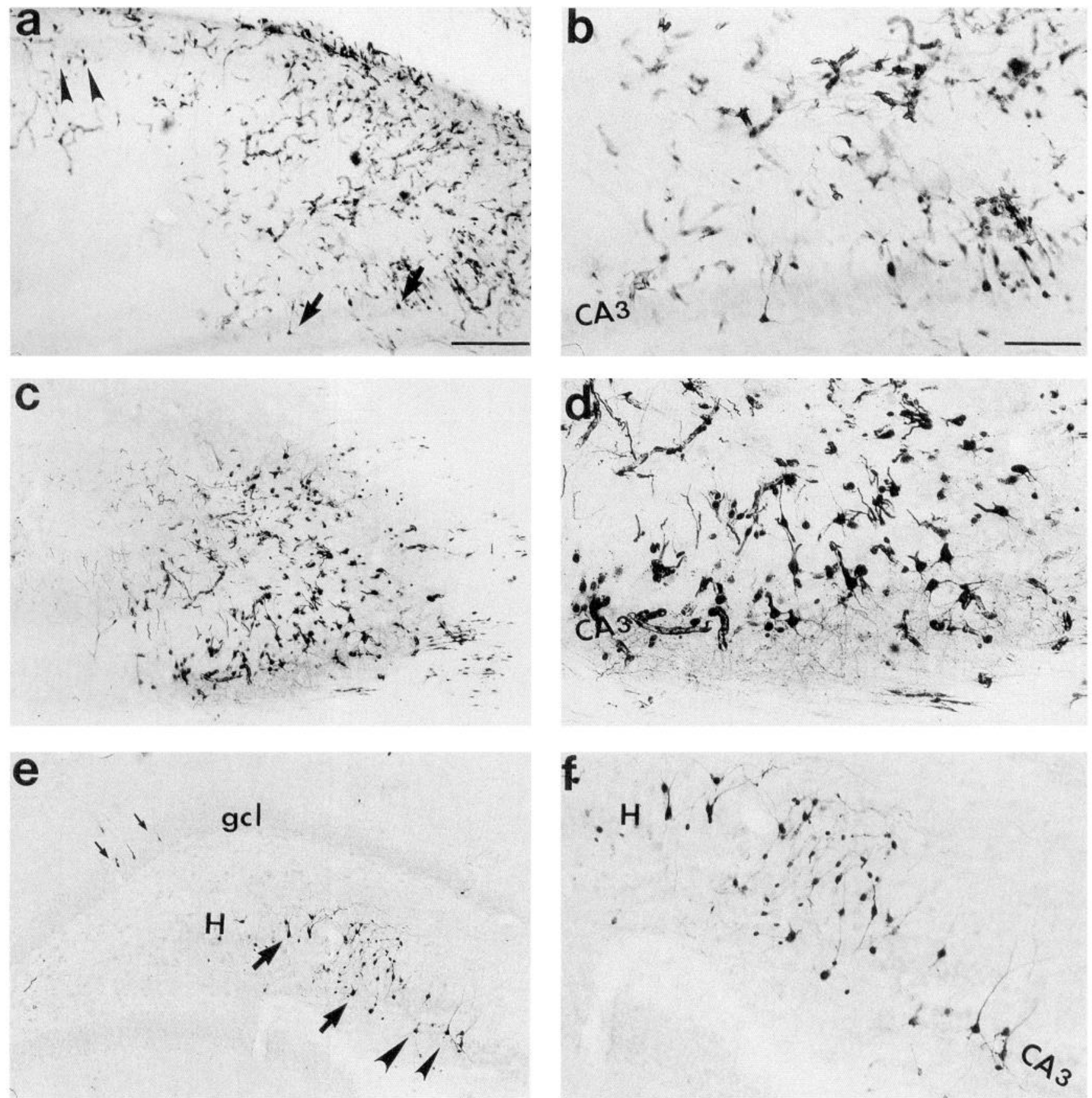

Figure 7. Temporal progression of RN33B cell survival and morphological differentiation in neonatal hippocampus. $\beta$-gal-IR RN33B cell transplants in coronal sections of hippocampus at $2(a, b), 5(c, d)$, and $16(e, f)$ weeks posttransplantation. $b, d$, and $f$ are higher magnification photomicrographs of the fields shown in $a, c$, and $e$, respectively. At 2 weeks posttransplantation $(a, b)$, many $\beta$-gal-IR RN33B cells are seen, the majority of which are undifferentiated. Some $\beta$-gal-IR RN33B cells in the pyramidal layer of CA1 (arrowheads in $a$ ) and CA3 (arrows $a$ and $b$ ) differentiated and extended apical and basal processes. At 5 weeks posttransplantation $(c, d)$, fewer $\beta$-gal-IR RN33B cells are detected but a higher percentage are morphologically differentiated (e.g., CA3 region in $d$ ). At 16 weeks posttransplantation $(e, f)$, most of the $\beta$-gal-IR RN33B cells have morphologically differentiated to assume phenotypes similar to neurons at the integration site. Some cells located in the granular cell layer $(\mathrm{gcl})$ have morphologies characteristic of endogenous granular neurons (small arrows). Many $\beta$-gal-IR RN33B cells are located in the hilar $(H)$ region (large arrows) and some in the CA3 pyramidal cell layer (arrowheads). Scale bars: $a, c$, and $e, 200 \mu \mathrm{m} ; b, d$, and $f$, $100 \mu \mathrm{m}$.

ronal phenotype of the transplanted RN33B cells. These data demonstrate that RN33B cells morphologically differentiate in response to regional microenvironmental cues, rather than follow a predetermined developmental fate.

Previous studies have demonstrated that immortalized, pluripotent, neuroepithelial precursor cell lines transplanted into the neonatal CNS can differentiate into both neuronal and glial cell types characteristic of the specific host regions. Renfranz et al. (1991) and Snyder et al. (1992) saw neuronal differentiation only into neuronal phenotypes that were undergoing neurogenesis at the time of transplantation. In contrast, Gao and Hatten (1994) described differentiation into multiple neuronal pheno- 

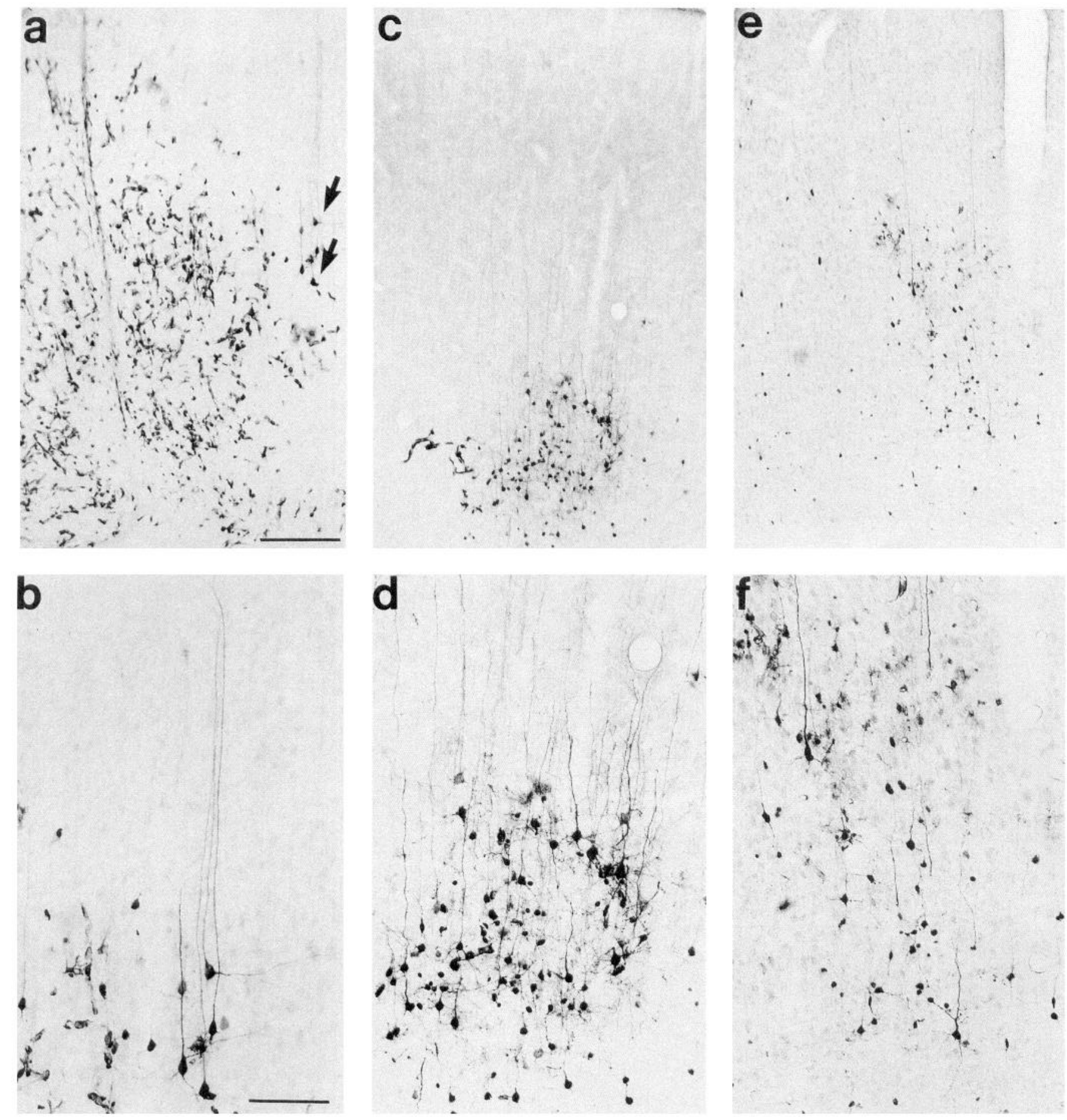

Figure 8. Temporal progression of RN33B cell survival and morphological differentiation in neonatal cerebral cortex. $\beta$-gal-IR RN33B cell transplants in coronal section of cerebral cortex at $2(a, b), 5(c, d)$, and $16(e, f)$ weeks posttransplantation. $b, d$, and $f$ are higher magnification photomicrographs of the fields illustrated in $a, c$, and $e$, respectively. At 2 weeks posttransplantation $(a, b)$, a large number of $\beta$-gal-IR RN33B cells are dispersed throughout the thickness of the neocortex. The majority of these cells are undifferentiated, but a few have morphologically differentiated to resemble cortical pyramidal neurons (arrows), as shown in $b$. Note the long apical processes extending towards the pial surface. At 5 weeks posttransplantation $(c, d)$, fewer cells are detected, but many more are morphologically differentiated. In $d$, a cluster of $\beta$-gal-IR RN33B cells located in deeper layers of the neocortex with morphologies similar to those of endogenous pyramidal cortical neurons is shown. At 16 weeks posttransplantation $(e, f)$, most $\beta$-gal-IR RN33B cells have differentiated phenotypes. Scale bars: $a, c$, and $e, 200 \mu \mathrm{m} ; b, d$, and $f, 100 \mu \mathrm{m}$.

types, both mitotically active and postmitotic, following transplantation of pluripotent granule cell precursors back into the cerebellum. All three groups defined multiple glial phenotypes. Similarly, we observed neuronal differentiation of RN33B cells in both adult and neonatal hippocampus and cerebral cortex into cell types that are born prenatally or postnatally (Altman and Bayer, 1990a,b; Bayer et al., 1991). We interpret these differences between the data to reflect intrinsic differences between 

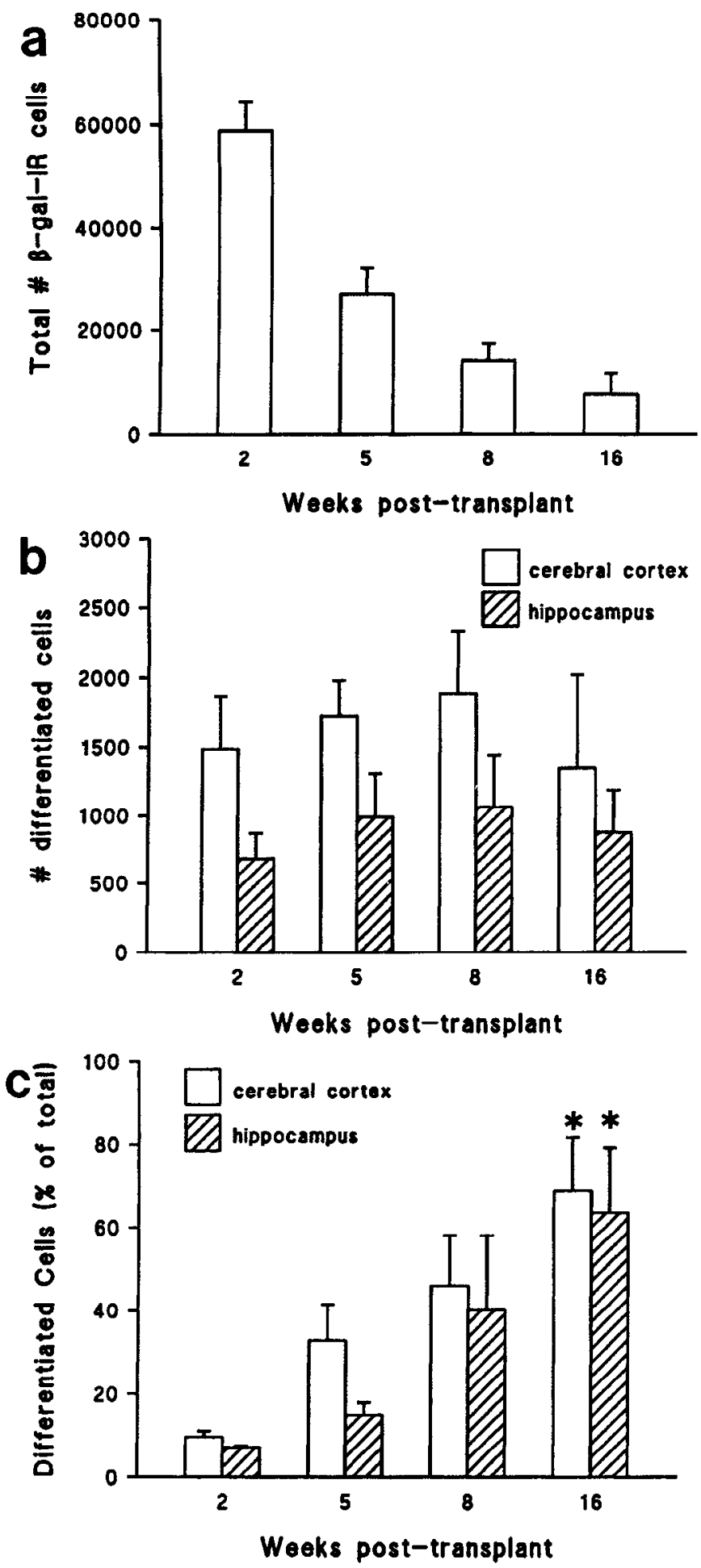

Figure 9. Temporal changes in $\beta$-gal-IR RN33B cell survival and differentiation following transplantation into the neonatal CNS. The total numbers of $\beta$-gal-IR RN33B cells were counted after variable posttransplantation survival intervals. Data represent the mean \pm SEM for four animals at each time point. $a$, The total number of RN33B cells significantly decreased with longer survival times in all regions (ANOVA, $\mathrm{df}=3,12, F=24.873, p<0.0001$ ). Posthoc analysis (unequal N LSD, $p<0.05)$ showed that all time points differed significantly with the exception of 8 and 16 weeks. $b$, Counts of the total number of differentiated RN33B cells at variable survival times demonstrate that the total number of differentiated RN33B cells did not change in the cerebral cortex (ANOVA, df $=3,12, F=0.267, p=0.847$ ) or in the hippocampus (ANOVA, $\mathrm{df}=3,12, F=0.374, p=0.773$ ) with longer the respective neuroepithelial precursor cell lines. Variables such as the lineage stage of the infected precursor, the transforming gene used, and the site of retroviral integration all influence the terminal differentiated phenotype of the transplanted precursor cell line (Whittemore et al., 1995). The fact that RN33B cells differentiate only into neurons likely reflects their initial immortalization at a developmental stage where they had already committed to a neuronal lineage. Consistent with this interpretation, peak neurogenesis in the raphe nucleus occurs between E13-14 (Lauder and Bloom, 1974) and RN33B cells were derived from E13 raphe nuclei. The ability of RN33B cells to differentiate with multiple morphologies in the hippocampus and cerebral cortex indicates that while these cells are neuronally restricted they have not yet become committed to one single neuronal phenotype. This conclusion is supported by in vivo data of cortical transplants of fetal tissue that suggest an early, transient, period during which the ultimate phenotype assumed by uncommitted, neuronally restricted precursor cells remains sensitive to environmental factors in the host (Barbe and Levitt, 1991).

Both genetic and extrinsic factors may regulate the lineage choices of multipotential progenitors (Anderson, 1989; McKay, 1989) and the area-specific distinctions of cerebral cortical neurons (Rakic, 1988; O'Leary, 1989). Transplantation experiments have shown that the host tissue environment may alter the differentiation and neural connections of transplanted, developing donor cells (Frank and Wenner, 1993; O'Leary and Koester, 1993). Multiple growth factors are responsible for neuronal survival and differentiation (Cattaneo and McKay, 1990; Chao, 1992; Collazo et al., 1992; Segal et al., 1992). The high levels of $\mathrm{p} 75^{\mathrm{NTR}}$, the presence of trkB mRNA, the expression of fulllength trkB receptor (Whittemore and White, 1993), the induction of $\mathrm{c}$-fos mRNA in response to BDNF treatment (data not shown), and the precise spatial differentiation of RN33B cells in CNS areas which produce high levels of BDNF and/or NT-3 and NGF (Enfors et al., 1990; Maisonpierre ct al., 1990), suggest that neurotrophin(s) may be also involved in RN33B differentiation in vivo.

Embryonic cerebellum transplants into the cerebellum of adult Purkinje cell degeneration mutant mice properly differentiate and integrate into the host circuitry (Sotelo and Alvarado-Mallart, 1986). Transplanted NTera 2 cells, a human tetratocarcinoma cell line capable of neuronal differentaition, establish molecular and structural polarity following transplantation into the adult rat brain (Trojanowski et al., 1993). Furthermore, long interfascicular growth of axons from ectopic embryonic neurons is observed along fiber tracts of adult brain and spinal cord (Fujii, 1991; Davies et al., 1993, 1994), indicating that the microenvironment of the adult host tracts provides sufficient cues to induce axon elongation in neurons that do not normally project through those specific tracts. Collectively, these data suggest that the adult CNS has the potential to direct the specific integration and differentiation of immature embryonic neuronal precursor cells.

$\leftarrow$

survival times. $c$, Counts of differentiated RN33B cells in cerebral cortex and hippocampus demonstrated a significant increase in the percentage of differentiated RN33B cells in the cerebral cortex (ANOVA, df $=3,12, F=6.225, p=0.008$ ) and in the hippocampus (ANOVA, $\mathrm{df}=3,12, F=4.454, p=0.025$ ) at longer survival times. The asterisk $(*)$ identifies time points that differed significantly from the 2 weeks time point using post hoc analysis, unequal N LSD, $p<0.05$. 
RN33B cells survive in both neonatal and adult hosts for $\geq 6$ months without forming tumors or otherwise distorting the organization of the host brain. While the phenotypes assumed by RN33B cells were similar in adult and neonatal hosts, there was a difference in the temporal pattern of survival and differentiation. There was an initial period of cell loss shortly after transplantation in adult hosts, but the total number of RN33B cells stabilized by 2 weeks posttransplantation. In contrast, more RN33B cells were seen at early posttransplantation times in neonatal hosts, but the total number of RN33B cells decreased with longer survival times. The increased initial survival of transplants within young hosts, is consistent with results with primary CNS grafts (Gage et al., 1983; Crutcher, 1990). By 16 weeks, the total number of RN33B cells was same in both adult and neonatal hosts, constituting about $6 \%$ of the total number of cells transplanted. The low number of surviving RN33B cells in adult and neonatal rat hosts at 16 weeks posttransplantation is also consistent with results from primary neuronal transplants where $<10 \%$ of the neurons routinely survive (Brundin and Björklund, 1987), but may also be due to the facts that RN33B cells were transplanted into an intact CNS. A recent study demonstrates that prior hippocampal lesion significantly improved fetal hippocampal graft survival (Shetty and Turner, 1995), presumably through induction of additional trophic support (Cotman et al., 1985).

The quantitative data represent the minimum estimate of surviving cells since exogenous gene expression driven from the murine Maloney leukemia virus (MMLV) LTR, such as the vector used here, has the potential to downregulate in vivo (Palmer et al., 1991; St. Louis and Verma, 1988; Onifer et al., 1993). However, these data do reflect the relative cell numbers and the extent of differentiation of transplanted, RN33B cells after variable survival times within and between different age groups. The percentage of morphologically differentiated RN33B cells in adults increased with longer survival times, but did not exceed $27 \%$ of remaining cells, whereas, the percentage of differentiated RN33B cells in neonates increased with longer survival times, reaching a maximum of $68 \%$ at 16 weeks posttransplant. As the total number of differentiated cells did not apparently change over time, the increase in the percent of differentiated cells was due to the loss of undifferentiated cells, suggesting that differentiated RN33B cells survive for long times in vivo. Moreover, 2 weeks was sufficient for the initial morphological differentiation of transplanted, RN33B cells in the neonatal CNS. One explanation for these data would be that endogenous levels of specific neurotrophic factors (Maisonpierre et al., 1990; Korsching, 1993), extracellular matrix (Sanes, 1989; Letourneau et al., 1994) and/or cell surface molecules (Stichel and Müller, 1992; Goodman and Shatz, 1993) have distinct patterns of spatial and temporal expression in the adult and neonatal CNS, and may differentially support the survival and differentiation of RN33B cells. The observed differences between adult and neonatal transplants further suggests that a distinct set(s) of effector molecule(s) was responsible for RN33B cell survival and differentiation.

Our results indicate that transplanted, immortalized, neuronal precursor cell lines are capable of extensive interactions with the host cells. Importantly, these cells survive chronically in both the adult and neonate CNS and maintain their differentiated neuronal phenotype. Such cell lines can be used in a variety of experimental paradigms to investigate discrete issues of developmental plasticity. Ultimately, appropriately derived immortal- ized cell lines may prove therapeutically useful as a means to replace endogenous CNS neurons lost as a result of trauma or neurodegenerative disease. This could result both because of the inherent plasticity of these neuronal cell lines, and more importantly, because of the capacity of the adult CNS to precisely direct specific differentiation and integration of the transplanted cells.

\section{References}

Altman J, Bayer SA (1990a) Migration and distribution of two populations of hippocampal granule cell precursors during the perinatal and postnatal periods. J Comp Neurol 301:365-381.

Altman J, Bayer SA (1990b) Prolonged sojourn of developing pyramidal cells in the intermediate zone of the hippocampus and their settling in the stratum pyramidale. J Comp Neurol 301:343-364.

Anderson DJ (1989) The neural crest cell lineage problem: neuropoiesis. Neuron 3:1-12.

Barbe MF, Levitt P (1991) The early commitment of fetal neurons to the limbic cortex. J Neurosci 11:519-533.

Bayer S (1980) Development of the hippocampal region in the rat. II. Morphogenesis during embryonic and early postnatal life. J Comp Neurol 190:115-134.

Bayer SA, Altman J, Russo RJ, Dai X, Simmons JA (1991) Cell migration in the rat embryonic neocortex. J Comp Neurol 307:499-516.

Björklund A (1991) Neural transplantation-an experimental tool with clinical possibilities. Trends Neurosci 14:319-322.

Björklund A, Stenevi U (1984) Intracerebral neural implants: neural replacement and reconstruction of damaged circuitries. Annu Rev Neurosci 7:729-308.

Brundin P, Björklund A (1987) Survival, growth and function of dopaminergic neurons grafted to the brain. Prog Brain Res 71:293-308.

Cattaneo E, McKay R (1990) Proliferation and differentiation of neuronal stem cells regulated by nerve growth factor. Nature 347:762765.

Cepko CL (1989) Immortalization of neural cells via retrovirus-mediated oncogene transduction. Annu Rev Neurosci 12:47-65.

Chao MV (1992) Neurotrophin receptors: a window into neuronal differentiation. Neuron 9:583-593.

Collazo D, Takahashi H, McKay RDG (1992) Cellular targets and trophic functions of neurotrophin-3 in the developing rat hippocampus. Neuron 9:643-656.

Cotman CW, Neito-Sampedro M, Whittemore SR (1985) Relationships between neurotrophic factors and transplant-host integration. In: Neural grafting in the mammalian CNS (Björklund A, Stenevi U, eds), pp 169-178. Amsterdam: Elsevier.

Crutcher KA (1990) Age-related decrease in sympathetic sprouting is primarily due to decreased target receptivity: implications for understanding brain aging. Neurobiol Aging 11:175-183.

Davies $\mathrm{SJ} \Lambda$, Field PM, Raisman G (1993) Long fibre growth by axons of embryonic mouse hippocampus neurons micro-transplanted into the adult rat fimbria. Eur J Neurosci 5:95-106.

Davies SJA, Field PM, Raisman G (1994) Intrafascicular axon growth from embryonic neurons transplanted into adult myelinated tracts. J Neurosci 14:1596-1612.

Emerich DF, Ragozzine M, Lehman MN, Sanberg PR (1992) Behavioral effects of neural transplantation. Cell Transplant 1:401-427.

Enfors P, Wetmore C, Olson L, Persson H (1990) Identification of cells in rat brain and peripheral tissues expressing mRNA for members of the nerve growth factor family. Neuron 5:511-526.

Fisher LJ, Jinnah HA, Kale LC, Higgins GA, Gage FH (1991) Survival and function of intrastriatally grafted primary fibroblasts genetically modified to produce L-dopa. Neuron 6:371-380.

Frank E, Wenner P (1993) Environmental specification of neuronal connectivity. Neuron 10:779-785.

Freed WJ, Morihisa JM, Spoor E, Hoffer BJ, Olson L, Seiger A, Wyatt RJ (1981) Transplanted adrenal chromaffin cells in rat brain reduce lesion-induced rotational behvior. Nature 292:351-352.

Frotscher M, Kraft J, Zorn U (1988) Fine structure of identified neurons in the primate hippocampus: a combined Golgi/EM study in the baboon. J Comp Neurol 275:254-270.

Fujii M (1991) Non-specific characteristics of intracerebral elongation from the olfactory bulb transplanted into the young adult host neo- 
cortex or hippocampal formation. Demonstrated immunohistochemically by the mouse Thy-1 allelic system. Neurosci Res 9:285-291.

Gage FH, Dunnett SB, Stenevi U, Björklund A (1983) Intracerebral grafting of neuronal cell suspensions. VIII. Survival and growth of implants of nigral and septal cell suspensions in intact brain of aged rats. Acta Physiol Scand 522:67-75.

Gage FH, Wolff JA, Rosenberg MD, Xu L, Yee JK, Shults C, Friedmann T (1987) Grafting genetically modified cells to the brain: possibilities for the future. Neuroscience 23:795-807.

Gage FH, Kajawa MD, Fisher LJ (1991) Genetically modified cells: applications for intracerebral grafting. Trends Neurosci 14:328-334.

Gage FH, Ray J, Fisher LJ (1995) Isolation, characterization, and use of stem cells from the CNS. Annu Rev Neurosci 18:159-192.

Gahwilar BH (1984) Development of the hippocampus in vitro: cell types, synapses and receptors. Neuroscience 11:751-760.

Gao W-Q, Hatten ME (1994) Immortalizing oncogenes subvert the establishment of granule cell identity in developing cerebellum. Development 120:1059-1070.

Gash DM, Collier TJ, Sladek JR (1985) Neural transplantation: a review of recent developments and potential applications to the aged brain. Neurobiol Aging 6:131-150.

Gash DM, Notter MFD, Okawara SH, Krause AL, Joynt RJ (1986) Amitotic neuroblastoma cells used for neural implants in monkeys. Science 233:1420-1422.

Gill TJ III, Kunz HW, Misra DN, Hassett ALC (1987) The major histocompatibility complex of the rat. Transplant 43:773-785.

Goodman CS, Shatz CJ (1993) Developmental mechanisms that generate precise patterns of neuronal connectivity. Neuron 10(Suppl):7798.

Hoffer BJ, Olson L (1991) Ethical issues in brain-cell transplantation. Trends Neurosci 14:384-388.

Horellou P, Brundin P, Kalen P, Mallet J, Björklund A (1990) In vivo release of DOPA and dopamine from genetically engineered cells grafted to the denervated rat striatum. Neuron 5:393-402.

Iaeger CB (1985) Immunocytochemical study of PC12 cells grafted to the brain of immature rat. Exp Brain Res 59:615-624.

Kordower JH, Notter MFD, Gash DM (1987) Neuroblastoma cells in neural transplants: a neuroanatomical and behavioral analysis. Brain Res 417:85-98.

Korsching S (1993) The neurotrophic factor concept: a reexamination. J Neurosci 13:2739-2748.

Lauder JM, Bloom FE (1974) Ontogeny of monoamine neurons in the locus coeruleus, raphe nuclei and substantia nigra of the rat. Cell Diff 155:469-482.

Letourneau PC, Condic ML, Snow DM (1994) Interactions of developing neurons with the extracellular matrix. J Neurosci 14:915-928.

Lindvall $\mathrm{O}$, Brundin P, Widner H, Rehncrona S, Gustavi B, Frackowiak R, Leenders KL, Sawle G, Rothwell JC, Marsden CD, Björklund A (1990) Grafts of fetal dopamine neurons survive and improve motor function in Parkinson's disease. Science 247:574-577.

Maisonpierre PC, Belluscio L, Friedman B, Alderson RF, Wiegand SJ, Furth ME, Lindsay RM, Yancopoulos GD (1990) NT-3, BDNF, and NGF in developing rat nervous system: parallel as well as reciprocal patterns of expression. Neuron 5:501-509.

McKay RDG (1989) The origins of cellular diversity in the mammalian central nervous system. Cell 58:815-821.

Nolan GP, Fiering S, Nicholas JF, Herzenberg LA (1988) Fluorescenceactivated cell analysis and sorting of viable mammalian cells based on a $\beta$-D-galactosidase activity after transduction of Escherichia coli lacZ. Proc Natl Acad Sci USA 85:2603-2607.

O'Leary DDM (1989) Do cortical area emerge from a protocortex? Trends Neurosci 120:400-406.

O'Leary DDM, Koester SE (1993) Development of projection neuron types, axon pathways, and patterned connections of the mammalian cortex. Neuron 10:991-1006.

Onifer SM, White LA, Whittemore SR, Holets VR (1993) In vitro strategies for identifying transplanted primary CNS tissue and neuronal cell lines. Cell Transplant 2:131-149.

Onifer SM, Whittemore SR, Holets VR (1993) Variable morphological differentiation of a raphe-derived neuronal cell line following transplantation into the adult rat CNS. Exp Neurol 122:130-142.

Palmer TD, Rosman GY, Osborne WRA, Miller AD (1991) Genetically modified skin fibroblasts persist long after transplantation but gradually inactivate introduced genes. Proc Natl Acad Sci USA 88:13301334.

Paxinos G, Watson C (1986) The rat brain in stereotaxic coordinates. San Diego: Academic.

Perlow MJ, Freed WJ, Seiger $\AA$, Olson L, Wyatt RJ (1979) Brain grafts reduce motor abnormalities produced by destruction of nigrostriatal dopamine system. Science 204:643-647.

Rakic P (1988) Specification of cerebral cortical areas. Science 241: 170-176.

Ramon y Cajal S (1988) Cajal on the cerebral cortex, pp 23-54. New York: Oxford UP

Renfranz PJ, Cunningham MG, McKay RDG (1991) Region-specific differentiation of the hippocampal stem cell line HiB5 upon implantation into the developing mammalian brain. Cell 66:713-729.

Sancs JR (1989) Extracellular matrix molecules that influence neural development. Annu Rev Neurosci 12:491-516.

Segal M, Greenberg B, Milgram NW (1986) A functional analysis of connections between grafed septal neurons and a host hippocampus. Prog Brain Res 71:349-358.

Segal RA, Takahashi H, McKay RDG (1992) Cellular targets and trophic functions of neurotrophin-3 in the developing rat hippocampus. Neuron 9:643-656.

Seiger $\AA$ (1985) Preparation of immature central nervous system regions for transplantation. In: Neural grafting in the mammalian CNS (Björklund A, Stenevi U, eds), pp 71-77. Amsterdam: Elsevier.

Shetty AK. Turner DA (1995) Enhanced cell survival in fetal hippocampal suspension transplants grafted to adult rat hippocampus following kainate lesions: a 3-dimensional graft reconstruction study. Neuroscience, in press.

Shimohama S, Rosenberg MB, Fagan AM, Wolff JA, Short MP, Breakefield XO, Friedmann T, Gage FH (1989) Grafting genetically modified cells into the rat brain: characteristics of $E$. coli $\beta$-galactosidasc as a reporter gene. Mol Brain Res 5:271-278.

Snyder EY, Deitcher DL, Walsh C, Arnold-Aldea S, Hartwieg EA, Cepko CL (1992) Multipotent neural cell lines can engraft and participate in development of mouse cerebellum. Cell 66:33-51.

Snyder EY, Taylor RM, Wolfe JH (1995) Neural progenitor cell engraftment corrects lysosomal storage throughout the MPS VII mouse brain. Nature 374:367-370.

Sotelo C, Alvarado-Mallart RM (1986) Growth and differentiation of cerebellar suspensions transplanted into the adult cerebellum of mice with heredodegenerative ataxia. Proc Natl Acad Sci USA 83:11351139.

St Louis D, Verma IM (1988) An alternative approach to somatic cell gene therapy. Proc Natl Acad Sci USA 85:3150-3154.

Stichel CC, Müller HW (1992) Expression of inherent neuronal shape characteristics after transient sensitivity to epigenetic factors. Dev Brain Res 68:149-162.

Trojanowski JQ, Mantione JR, Lec JH, Seid DP, You T, Inge LJ, Lee VM-Y (1993) Neurons derived from a human tetratocarcinoma cell line establish molecular and structural polarity following transplantation into the rodent brain. Exp Neurol 122:283-294.

White LA, Keane RW, Whittemore SR (1994) Differentiation of an immortalized CNS neuronal cell line decreases their susceptibility to cytotoxic $T$ lymphocyte cell lysis in vitro. J Neuroimmunol 49:135143.

Whittemore SR, White LA (1993) Target regulation of neuronal differentiation in a temperature-sensitive cell line derived from medullary raphe. Brain Res 615:27-40.

Whittemore SR, White LA, Shihabuddin LS, Eaton MJ (1995) Phenotypic diversity in neuronal cell lines derived from raphe nucleus by retroviral transduction. In: Methods, a companion to Methods in enzymology, Vol 7 (Russo A, Green S, eds), pp 285-296. San Diego: Academic.

Widner H, Brudin P (1988) Immunological aspects of grafting in the mammalian central nervous system. A review and speculative synthesis. Brain Res Rev 13:287-324. 